\title{
Basic theories of modern institutionalism
}

\author{
Ayna Salamova* \\ Chechen State University, Sheripova st., 32, 364024 Grozny, Russia
}

\begin{abstract}
Institutionalism went through a difficult historical path of its development, went through several stages, each of which was accompanied by the renewal of methodology and theoretical foundations. Consistently at each stage, a corresponding independent direction arose: old institutionalism, new institutionalism (new institutional economics) and neoinstitutionalism (neoinstitutional economics). Modern institutionalism is a qualitatively new direction of economic thought, based on the theoretical principles of economic analysis of the neoclassical school in terms of identifying trends in the development of the economy, as well as the methodological tools of the German historical school in the approach to the study of socio-psychological problems of the development of society.
\end{abstract}

\section{Introduction}

New institutional economics is one of the youngest currents of economic thought that has made significant strides in promoting their theoretical concepts, ideas and analytical tools. It emerged, like traditional institutionalism, as a criticism of neoclassical orthodoxy, neoinstitutionalism itself became, in time, in fact a part of neoclassicism (although not all economists admit it). At present, the majority of scientific journals devote a great deal of space to publications in the context of the theory of new institutional economics, which cannot be said about other currents of institutionalism [1].

Institutionalism has absorbed many of the ideas of the German historical school, the English Fabians, and the French sociological tradition. The influence of Marxism on institutionalism cannot be denied either. The old institutionalism emerged at the end of the 19th century. and took shape as a current in 1920-1930. He tried to occupy the "middle yuyu lyn yu" between non-classical "economics" and Marxism.

In 1898, Thorstein Veblen (1857-1929) wrote a critique of G. Schmoller, a leading representative of the German school of history, for an overwhelming empirical revision. Trying to answer the question "Why is economics not an evolutionary science", instead of a narrowly economic one, he proposes an interdisciplinary approach that would include social philosophy, anthropology, and psychology. This was an attempt to turn economic theory towards social issues.

In 1918, the concept of "institutionalism" also appeared. It is introduced by Wilton Hamilton. He defines the institution as "a sparse way of thinking or acting, embodied in group habits and customs of the people." From his point of view, the institutes of fixity are well-established procedures, reflecting the general agreement, the agreement that has

\footnotetext{
*Corresponding author: salamova_chgu@mail.ru
} 
developed in society. By institutions, they meant customs, corporations, trade unions, the state, etc. Such an approach to the understanding of institutions is typical for traditional ("old") institutionalists, to which Famous economists such as Thor Stein Veblen, Wesley Claire Mitchell, John Richard Common, Car 1-August Wittfogel, Gunn ar Muredahl, John Kenn et Galbraith, Robert Heilbr on er. Let's get to know the concepts of some of them a little closer [2].

In 1899, Thorstein Veblen's book, "Theory of the Primary Class. The Economic Study of Institutions," was published, the first mono- graphic study based on a consistent institutional methodology. Inspired by the ideas of the social gift of vinism, Veblen examined the natural selection of institutions in Theory of Primary Class. The institution of the primitive class is the activity of the ruling elite, which emphasizes its privileged position with respect to the consumption. Veblen studied this institute as contemporary anthropologists studied the customs of the African tribes. He believed that this institute is a private one, which he declared "the laws of predation and parasitism" and hinders the development of society due to inertia, conspicuous waste and a system of inappropriate distribution of welfare.

In the book "Theory of Business Administration" (1904) T. Veblen analyzes the dichotomy of industry and business, rationality and irrationality [4]. It contrasts the behavior caused by actual knowledge, the behavior determined by the habits of thinking, considering the first as a source of change in the process, and the second as a factor counteracts him.

In works written during the years of the first world war and after it - "The instinct of skill and state of industrial skills" (1914), "The place of science in modern civilization "(1919)," Engineers and the system of prices "(1921) - Veblen examined important problems of the scientific and technological process, emphasizing the insight into the role of" technology envi ronments "(engineers, scientists, managers) in the creation of a rational industrial system. It was with them that he linked the future of capitalism [7].

\section{Comparative characteristics of the "old" and "new" institutionalism}

Although institutionalism as a special trend was formed at the beginning of the twentieth century, for a long time it was on the periphery of economic thought. The explanation of the movement of economic benefits only by institutional factors did not find a large number of supporters. This was partly due to the vagueness of the very concept of "institution", by which some researchers understood mainly customs, others - trade unions, still others - the state, fourth corporations - etc., etc. Partly - with that, that institutionalists tried to use the methods of other social sciences in economics: law, sociology, political science, etc. As a result, they lost the ability to speak the single language of economic science, which was considered the language of graphs and formulas. There were, of course, other objective reasons why this trend was not in demand by contemporaries [9].

The situation changed dramatically in the 1960s and 1970s. To understand why, it is sufficient to draw at least a cursory comparison of the "old" and "new" institutions. Between the "old" institutionalists (such as T. Veblen, J. Commons, J.C. Galbraith) and non-institutionalists (such as R. Coase, D. North, or J. Buchanan) there are, on the smallest measure, three radical differences [5-6].

First, the "old" institutionalists (for example, J. Commons in "The Right Basics of Capitalism") went to the economy from law and politics, trying to study the problems of the modern economy. ohmic theory and methods of other sciences about society; Noninstitutionalists go directly in the opposite way - they study political science and legal 
issues using the methods of non-classical economic theory, and above all, with the application of the apparatus of modern microeconomics and game theory.

Secondly, traditional institutionalism was based mainly on the inductive method, trying to go from particular cases to generalizations, as a result of which the general institutional theory did not e developed; neoinstitutionalism proceeds deductively - from general principles of non-classical economic theory to the explanation of specific phenomena of public life (Table 1) [7].

Table 1. Fundamental differences between "old" institutionalism and neoinstitutionalism

\begin{tabular}{|c|c|c|}
\hline Signs & Old institutionalism & Neo-institutionalism \\
\hline Motion & $\begin{array}{c}\text { From law and politics } \\
\text { to the economy }\end{array}$ & From economics to politics and law \\
\hline Methodology & $\begin{array}{c}\text { Other humanities (law, political } \\
\text { science, sociology, etc.) }\end{array}$ & $\begin{array}{c}\text { Economic neoclassical (methods of } \\
\text { microeconomics and game theory) }\end{array}$ \\
\hline Method & Inductive & Deductive \\
\hline Focus of attention & Collective action & Independent individual \\
\hline $\begin{array}{c}\text { Analysis } \\
\text { prerequisite }\end{array}$ & Holism & Methodological individualism \\
\hline
\end{tabular}

Thirdly, the "old" institutionalism, as the course of radical economic thought, acquired a predominantly the interests of the individual; neoinstitutionalism, on the other hand, puts at the forefront of the independent individual who, of his own free will and in accordance with his interests, decides which collectives it is beneficial for him to be a member of [3].

In the last decades, there has been an increase in interest in institutional research. This is partly due to an attempt to overcome the limitation of a number of assumptions that are characteristic of economics (axioms of complete rationality, absolute information, perfect competition, the establishment of equilibrium only by means of the price mechanism, etc.) and to consider modern economic, social and political processes is more complex and allround; partly - with an attempt to analyze the phenomena that arose in the era of HTP, the use of which does not give the desired result by traditional methods of research. Therefore, let us show from the beginning how the development of the premises of the non-classical theory of the interior took place.

\section{The main directions of neoinstitutional theory}

A unified classification of institutional theories has not yet been developed. First of all, the dualism of the "old" institutionalism and non-institutional theories is still preserved. Both of the rise of modern institutionalism were shaped either on the basis of non-classical theory, or under its essential influence. Thus, neoinstitutionalism developed, broadening and supplementing the magistracy of the "economics".Invading the spheres of other sciences about society (law, sociology, psychology, politics, etc.), this school used traditional microeconomic methods of analysis, trying to investigate all social relations from the standpoint a rationally thinking "economic man" (homo oeconomicus). Therefore, any relationship between people is considered here through a process of mutually beneficial exchange. Such an approach is modernly called by J. Common a counter (contractual) pair adigma [6].

If, in the framework of the new direction (non-institutional economics), the institutional approach has only expanded and modified traditional neoclassicism, remaining within its limits and removing only some of the most unrealistic preconditions (axioms of complete rationality, absolute information, perfect competition, the establishment of equilibrium only through the price mechanism, etc.), then the second direction (institutional economics) to a much greater extent and was based on the "old" institutionalism [10]. 
If the first direction ultimately strengthens and expands the non-classical pair adigm, subordinating to it all new and new spheres of research (family relations, ethics, political life and, inter-racial relations adolescence, admittance, historical development of society, etc.), then the second April comes to the full neglect of June neoclassicism, giving rise to institutional economics opposed to neoclassical "main str imu" [5]. This modern institutional economics rejects the methods of marginal and equitable analysis, taking on the evolutionary sociological methods. Therefore, the representatives of these schools choose areas of analysis that go beyond the boundaries of the market economy (problems of creative labor, overcoming private property, liquidating exploitation, etc.). Relatively isolated within the framework of this April is only the French economy of agreements, trying to bring a new basis for non-institutionalized economy and, above all, under its control. steam adigma. This basic, from the point of view of the representatives of the economy of agreements, are norms.

\section{New institutionalism}

In the modern theory, institutions are understood as the "rules of the game" in society or, "man-made" limited frameworks that organize relationships between people, as well as a system of measures, ensuring their enforcement [8]. They create structures around the motivating motives of human interaction, and they reduce the uncertainty by organizing everyday life. Institutions are divided into formal (as of April, the US Constitution) and non-formal (as of April, Soviet "telephone right").

Informal institutions are commonly understood as generally accepted conventions and codes of ethics for human behavior. These are customs, "laws", habits or normative rules that are the result of the close coexistence of people. Thanks to them, people will easily find out what the people around them want from them, and they will well understand other things. These codes of conduct for the world of cultures [6]. Formal institutions are understood as rules created and supported by specially empowered people (government officials).

The process of formalization of limits is associated with an increase in their return and reduction of costs by introducing unified standards. The costs of protection of the rule are connected, in turn, with the establishment of the fact of abuse, the measurement of the degree of abuse and the punishment of the abuse, provided that the ultimate benefits are They increase the costs, or, in any case, not higher than them. Property rights are realized through a system of stimuli (anti-stimuli) in a set of alternatives that stand in front of economic agents. The choice of a defined action control is completed by the conclusion of a contract.

\section{Conclusions}

In 2000, David Kolander, speaking about the economic policy of the third millennium, noted that the policy of "right prices" was replaced by "a modern approach to politics, built on the basis of incipe of the "proper institutes" [5]. In other words, institutional research in the economy has long been "pure science", realizing its practical need. That is why it is so important to develop this application of research in our country. The modern Russian institutionalists, having overcome the Soviet legacy of harsh opposition to the institutional approach in the economy, have become Work in several bases on april.

The first direction, which can be called educational and analytical, presents to the domestic audience the most important achievements of the world institutional economy from theoretical concepts to analytical schemes and institutional analysis tools. The second 
direction is the development of educational materials on institutional economics, based, as a rule, on world achievements. The third direction has a predominantly applied character, when the categorical apparatus and instruments of the institutional approach are used to analyze the phenomena of the Russian economy. These trends, which today constitute the dominant group of modern institutional research in Russia, unite the backing of the accomplishments of established institutionalists. The main result of the work of researchers in the three aprilments noted was the establishment of institutionalism as a conventional and promising section of modern economic analysis.

\section{References}

1. E.V. Efimov, Issues of Economics, 49 (2019)

2. O. Inshakov, Economist, 39 (2018)

3. R.M. Nureev, Essays on the History of Institutionalism Humanitarian Perspectives (2020)

4. A.D. Frolov, Issues of Economics, 130 (2018)

5. A.G. Khudokormov, History of Economic Studies (2017)

6. Institutional Economics: Educational (2017)

7. B.V. Korneychuk, Institutional Economics (2018)

8. R.M. Nureev, Essays on the History of Institutionalism Humanitarian Perspectives (2018)

9. D. Frolov, Issues of Economics, 130 (2018)

10. R.M. Nureev, Institutional Economics, 704 (2019) 